\begin{tabular}{cc}
\hline \multicolumn{1}{c}{ A N N A L E S } \\
UNIVERSITATIS MARIAE CURIE-SKŁODOWSKA \\
LUBLIN - POLONIA \\
VOL. XXV,1 & SECTIOK \\
\hline
\end{tabular}

Wydział Ekonomiczny Uniwersytetu Gdańskiego

EWA POLAK

\title{
Zacieranie granic i rozmywanie znaczeń jako jedna z tendencji wspótczesnych przemian cywilizacyjnych
}

Blurring Borders and Changing Meanings As One of the Tendencies of Contemporary

Civilizational Changes

\begin{abstract}
ABSTRAKT
Celem przeprowadzonej analizy jest próba identyfikacji i zdefiniowania kierunków współczesnych przemian kulturowych, ich istoty, przyczyn i konsekwencji oraz konfliktów powstałych na tle przedstawionych procesów. Konflikty te dotyczą zarówno styku różnych kultur, jak i odmiennych postaw wobec coraz szybszego tempa zmian i ich kierunków w ramach jednego kręgu społeczno-kulturowego.

Struktura pracy obejmuje wstęp, sześć rozdziałów i zakończenie.

W rozwiązaniu problemu badawczego przyjęto następujące metody i techniki badawcze: analizę literatury przedmiotu i doniesień prasowych, metodę wzorca oraz obserwację bezpośrednią i pośrednią. Kwerenda literatury przedmiotu umożliwiła konfrontację własnych przemyśleń i obserwacji z dotychczasowymi ustaleniami badawczymi. Wykorzystano również metodę polegającą na syntetyzowaniu rozproszonych informacji i obserwacji oraz formułowaniu na tej podstawie określonych wniosków opartych na zasadach analizy logicznej i dedukcji.
\end{abstract}

Słowa kluczowe: zacieranie granic, rozmywanie znaczeń, przemiany cywilizacyjne

\section{WSTĘP}

Jedną z tendencji nasilających się współcześnie jest rozmywanie się granic pomiędzy odmiennościami, skracanie dystansu między skrajnościami, inflacja pojęć, zmiana znaczeń i kryteriów ocen. Procesy z tym związane są konsekwencją globalizacji, komercjalizacji wszystkich dziedzin życia, rosnącej roli mass mediów 
i internetu i rozwoju manipulacyjnych technik oddziaływania na ludzi. Konsekwencją zachodzących procesów jest przesuwanie, unieważnianie granic, zanikanie sfery tabu i sacrum, zmiana kryteriów wartości, dezorientacja ludzi, relatywizm rozumiany jako obojętność, znieczulenie, przyzwolenie na więcej/na wszystko. Przyczynia się to do utraty przekonań, osobowości, wykształcania postaw zewnętrzsterownych. Ludzie bez własnych poglądów, tożsamości, wartości są zdezintegrowani, zagubieni i łatwiej nimi kierować i manipulować. Zatarciu ulega najważniejsza granica - pomiędzy dobrem i złem - i relatywizm w rozumieniu tych pojęć. Rozmywanie granic ułatwia ich przekraczanie i akceptację dla działań bezprawnych.

\section{KULTURA - NATURA}

Jeżeli przyjmie się, że wszystko, co nas otacza, należy do natury albo kultury (wytworów działalności człowieka), to można stwierdzić, że w miarę rozwoju cywilizacyjnego kurczy się sfera natury. Dobra kultury coraz umiejętniej naśladują naturę, a naturalne od sztucznego coraz trudniej odróżnić. Człowiek ingeruje w naturę, zmienia ją lub niszczy. Degradacji ulega środowisko naturalne, znikają z powierzchni ziemi lasy, łąki, wodne zbiorniki. W to miejsce powstają sztuczne jeziora, sztuczne koryta rzek, genetycznie modyfikowane nowe odmiany roślin i zwierząt. Atrybutem natury przestały być takie kojarzone z nią wcześniej zjawiska, jak: kolor włosów, rysy twarzy, tusza, wzrost, gestykulacja, mimika twarzy, tembr głosu, starzenie się. We wszystko to ingeruje coraz bardziej człowiek, przekształcając siebie i otaczające go środowisko zgodnie z oczekiwaniami współczesnej kultury. Modyfikuje się zachowania ludzi, m.in. jako konsumentów, pracowników, wyborców, inwestorów, dzięki coraz powszechniejszemu wykorzystywaniu wiedzy psychologicznej w polityce, biznesie czy szerzej - relacjach interpersonalnych. Czas biologiczny zastąpiono czasem kulturowym. Rosnącym zainteresowaniem i zastosowaniem cieszą się narzędzia PR, marketingu czy nawet neuromarketingu. Swoje odpowiedniki mają niemal wszystkie pochodzące z natury towary, są sztuczne diamenty, perły, skóra, kwiaty itp. Sztuczny jest zapach i kolor chleba i w sposób sztuczny, wyprany z emocji zwraca się do klienta pracownik banku. W komercyjnej rzeczywistości (sklepy, miejsca pracy, instytucje usługowe itp.) i relacjach międzyludzkich coraz ważniejsze stają się scenariusz i scenografia. Tak więc środowisko człowieka, a także on sam i jego zachowania, reakcje, wizerunek ulegają coraz większemu usztucznieniu [Polak 2012: 185].

\section{DETERYTORIALIZACJA WYTWORÓW KULTURY}

Do rozmywania granic i wymieszania różnorodności przyczyniają się też procesy globalizacji, które powodują m.in. deterytorializację zjawisk i procesów kulturowych, stąd np. można zobaczyć góralską bacówkę na plaży Bałtyku, chińskie, indyjskie czy 
tajskie restauracje w dowolnym miejscu świata, fast foody oferujące wszędzie regionalną żywność, można kupić afrykańskie maski na ulicy w Warszawie czy Brukseli, spędzić czas na egzotycznej morskiej plaży w okolicach Berlina, bawić się przy dźwiękach afrykańskiej etnicznej muzyki na dyskotece w Moskwie lub poczuć smak egzotycznych podróży, odwiedzając odpowiedni park tematyczny, kopie słynnych zabytków lub kino wyświetlające filmy w technice 3D. Dobra kultury materialnej i duchowej wyrwano z ich lokalnego kontekstu i są elementem globalnej oferty komercyjnej. Zostały oderwane od swoich korzeni i straciły pierwotne, oryginalne znaczenie. Większość produktów lokalnych/regionalnych jest wytwarzana w globalnych fabrykach Chin i krajów z nimi sąsiadujących. Trudno więc rozpoznać miejsce pochodzenia towarów i zrozumieć genezę i sens istnienia wielu dóbr rynkowych.

Skróceniu ulega też dystans pomiędzy globalnym i lokalnym. Globalizacja wkracza w życie lokalne, zmienia je, imituje albo niszczy lokalność. Lokalność z kolei uniezależnia się od miejscowych uwarunkowań i udaje globalność.

\section{PRZEMIANY SPOŁECZNO-KULTUROWE}

Zatarciu ulegają granice pomiędzy kulturami. W warunkach globalizacji obserwuje się dyfuzję obcych wpływów, wzajemne przenikanie wzorców kulturowych, akulturację, hybrydyzację kulturową. Większość współczesnych kultur charakteryzuje eklektyzm, synkretyzm, wewnętrzna dezintegracja. Jednocześnie rosną kompetencje do komunikacji międzykulturowej. Powstaje syntagma kulturowa - wspólny mianownik norm, wartości, zachowań, akceptacja i zrozumienie zarówno dla wytworów kultury wyższej, jak i osiągnięć kultury materialnej. Coraz częściej aspiracje i wybory rynkowe ludzi nie zależą od kręgu kulturowego, z którego się wywodzą, ale od zasobności portfela i możliwości uczestnictwa w globalnej ofercie kulturowej. Pomostem pomiędzy kulturami jest często amerykańska kultura popularna - atrakcyjna i zrozumiała dla większości ludzi. Niejednoznaczna wydaje się też granica pomiędzy kulturą wyższą i niższą, sacrum a profanum, wydarzeniem kulturalnym a happeningiem i prowokacją.

Przemiany kulturowo-cywilizacyjne są przyczyną rozmycia granic pomiędzy rasami (mówiąc bardziej poprawnie politycznie - pomiędzy odmianami człowieka). Ruchy ludnościowe powodują wzajemne wymieszanie narodowości, ras, kultur. Ze względu na kraj pochodzenia przodków można utożsamiać się z kilkoma narodowościami, kulturami, religiami. W USA powołano do życia liczącą kilkanaście milionów członków Koalicję Wielorasowców, skupiającą ludzi będących mieszanką różnych ras i nieutożsamiającą się do końca z żadną z nich

1 W specjalnie wydanym albumie fotograficznym Part Asian. 100\% Hapa K. Fulbeck i S. Lennon przedstawiali wzorcowe postacie społeczności planetarnej określających się jako „Hapa”. Na zdjęciu pojawia się np. ciemna brunetka o jasnej karnacji skóry, azjatyckim kształcie nosa, która mówi o sobie, że jest mieszanką elementów tajskich, indyjskich, szkockich i litewskich. Albo chłopczyk o blond włosach, jasnej cerze i skośnych czarnych oczach. Jego korzenie są w Chinach, Norwegii i Niemczech. Setki fotografii 
Ostatnio lansuje się też pogląd o niejednoznacznych kryteriach określających płeć. Obok tradycyjnego podziału na płeć męską i żeńską występują podziały, w których wymienia się formy pośrednie płci i różne relacje między płciami - transpłciowość, biseksualność, homoseksualność, interseksualność, transwestytyzm, nieheteronormatywność, transgenderyzm, agenderyzm, trzeci rodzaj. Oprócz płci biologicznej zwraca się coraz częściej uwagę na istnienie płci kulturowej, która może być niezgodna z płcią biologiczną. Jest ona przedmiotem wyboru człowieka i może wielokrotnie w ciągu jego życia ulegać zmianie.

Coraz bardziej niejednoznaczne wydaje się pojęcie młodości, wieku dojrzałego, starości. Dzięki postępowi medycyny, wydłużeniu się życia ludzkiego i zmianom cywilizacyjnym polegającym m.in. na kulcie młodości, ciągłym przesunięciom i rozmyciu ulegają cezury czasowe związane z kolejnymi etapami życia. Przestaje być z nimi związany określony styl życia, sposób ubierania się, cele życiowe i aspiracje. Operacje plastyczne pozwalają przywrócić młody wygląd. Spotkać można zdrowych, energicznych, pracujących zawodowo, podejmujących studia w wyższych uczelniach, biorących udział w biegach maratońskich i skaczących ze spadochronem siedemdziesięcio- i osiemdziesięciolatków. Przyjęło się uważać, że mamy tyle lat, na ile się czujemy.

Zacierają się też granice pomiędzy sferą publiczną i prywatną. Powszechnym zjawiskiem jest upublicznianie prywatnych problemów. Dzięki internetowi można zaistnieć chociaż na chwilę w przestrzeni publicznej, publikując w sieci film z wakacji, uroczystości rodzinnej, zabawnego wydarzenia, narodzin dziecka czy nocy poślubnej. Pewna grupa osób, tzw. celebryci, traktują to wręcz jako sposób na życie i karierę. Intymność przestała być intymnością i stała się poszukiwanym towarem. Ponadto w czasie prywatnym i przestrzeni prywatnej człowiek jest atakowany z zewnątrz np. za pośrednictwem telefonów komórkowych, jego prywatna aktywność może być śledzona w Internecie, za pośrednictwem GPS, ulicznych kamer czy miejsca użycia kart płatniczych.

Współcześnie tradycyjne stosunki społeczne i wspólnoty wypierane są przez relacje komercyjne, a wartości komercyjne udają tradycyjne. Ludzie coraz więcej czasu spędzają w sztucznym, wykreowanym środowisku i nieautentycznych sytuacjach (cyberprzestrzeń, centra handlowe, parki rozrywki, „wspólnoty” komercyjne, „wspólnoty” prestiżowe), w których obowiązują określone standardy zachowań i kody porozumiewania.

Człowiek żyje w dwóch równoległych światach - realnym i w cyberprzestrzeni. Granice pomiędzy światem realnym i wirtualnym są coraz płynniejsze. Duża anonimowość kontaktów w sieci pozwala udawać kogoś innego i żyć w nierealnym świecie. Rośnie liczba społeczności wirtualnych, w których „przyjaciół” się kolekcjonuje, zmienia, edytuje i w których można wybrać dowolną tożsamość sieciową. Ludzie tworzą własne cyberświaty (np. gra Second Life). Blogi, osobiste dzienniki

i setki wyznań o sobie, o sposobach szukania własnej tożsamości, o próbach odpowiedzi na pytanie: kim jestem lub czego jestem częścią? [Fulbeck, Spickard, Lennon 2006]. 
prowadzone w sieci rozmyły sferę osobistą. Internet zaciera też granice profesjonalizmu - każdy jego użytkownik może ocenić pisarza, aktora, wykładowcę, nie ponosząc odpowiedzialności za swoje słowa. Zbyt duże uzależnienie od sieci może utrudniać kontaktowanie się ze światem rzeczywistym. Psychologowie zauważyli już, że dzieci w krajach wysoko rozwiniętych często traktują rzeczywistość jako poszerzenie świata wirtualnego. Współczesna technika zachęca do aspołecznych zachowań i staje się substytutem życia.

Rozmywają się w związku z tym granice pomiędzy światem prawdziwym a wirtualnym, rzeczywistością a kreacją, scenografią, spektaklem, osobowością a odgrywanymi rolami i wykreowanym wizerunkiem.

W miarę rozwoju nauki coraz bardziej niejednoznaczne wydają się podziały na dyscypliny i dziedziny wiedzy. $Z$ jednej strony zwiększa się specjalizacja wiedzy, $z$ drugiej natomiast powstają nowe obszary badawcze, na pograniczu tych tradycyjnych. Wobec rosnącego zasięgu, gęstości, intensywności, różnorodności wzajemnych wpływów oddziaływań, zależności rośnie znaczenie badań interdyscyplinarnych, np. socjologia polityki, ekonomika kultury, ekonomia behawioralna, geografia ekonomiczna, biochemia, ekofilozofia.

\section{USUWANIE GRANIC W GOSPODARCE I NA RYNKU PRACY}

W dobie globalizacji i związanych z nią: offshoringiem, outsourcingiem i wirtualizacją gospodarki, swoje granice, określane kiedyś własnością budynków z nazwą/ logo firmy i ogrodzonego terenu, straciło też przedsiębiorstwo. Produkcję można bowiem przenieść za granicę, można zlecić pewne procesy wytwórcze zewnętrznym anonimowym firmom, można w końcu przenieść działalność gospodarczą do świata wirtualnego. Firmy łączą się, przejmują się nawzajem, zawierają sojusze strategiczne, wydzierżawiają swoje logo. Coraz trudniej w związku z tym ustalić pochodzenie towarów. Przedsiębiorstwa stały się współcześnie coraz bardziej mobilnymi podmiotami gospodarczymi bez granic. Rozmyciu uległo rozróżnienie pomiędzy krajowym i zagranicznym [Bauman 2006].

Postęp naukowo-techniczny i rozwój społeczny powodują rozmycie linii podziału pomiędzy czasem nauki, czasem pracy, czasem odpoczynku; aktywnością i biernością zawodową; zatrudnieniem i bezrobociem. Dzięki nowoczesnym środkom komunikacji zawodowo pracuje się w domu, w samolocie, na urlopie. Część zatrudnionych pracę zawodową traktuje jako pasję i hobby. Zatarciu ulega też podział na dni świąteczne i robocze [Sztumski 2015].

Liberalizacja i deregulacja, jako procesy towarzyszące globalizacji, dają pracodawcom coraz większą swobodę w zakresie decydowania o warunkach pracy. Presja globalnej konkurencji wymusza oszczędności na kosztach pracy. Rośnie więc ilość form pośrednich między zatrudnieniem a bezrobociem, pracą etatową a zatrudnieniem (zatrudnienie w niepełnym wymiarze godzin, zatrudnienie czasowe, zatrudnienie na 
podstawie umowy cywilno-prawnej, zatrudnienie pod warunkiem wcześniejszego samozatrudnienia, praca na wezwanie, zatrudnienie niezgodne z kwalifikacjami, darmowe lub nisko płatne staże pracy, praca w szarej strefie itp.), które jest związane z uzyskiwaniem niższych dochodów i niewielkimi perspektywami dalszej kariery. Zatarciu ulega więc granica pomiędzy stanem zatrudnienia i bezrobocia. Pracownikowi na wezwanie czy stażyście wykonującemu darmową lub nisko płatną pracę prawdopodobnie trudno jest odpowiedzieć na pytanie, czy czuje się bardziej zatrudnionym czy bezrobotnym.

Współcześnie problematyczna wydaje się też próba odpowiedzi na pytanie: kim jestem? Kiedyś odpowiedź na to pytanie była jednoznaczna i stała. Współcześnie jest inaczej, tożsamość ulega zatarciu, jest bez wyraźnych granic, wielowymiarowa, zmienna. I tak, dziś ktoś jest mężczyzną, Polakiem urodzonym w Poznaniu i mieszkającym w Niemczech w Berlinie, zwolennikiem socjaldemokracji i New Age, osobą pracującą zawodowo, pracownikiem firmy turystycznej, a jutro? I jak odpowiedzieć na pytanie o tożsamość, jeżeli przodkowie pochodzą z różnych kultur, ras, narodowości, religii, a ktoś np. ma wykształcenie medyczne, ale nie pracuje w swoim zawodzie?

\section{SKRACANIE DYSTANSÓW I ROZMYWANIE POJĘĆ W POLITYCE}

Zatarciu ulegają granice pomiędzy państwami, na skutek coraz ściślejszej współpracy międzynarodowej, rosnącej liczby globalnych i regionalnych organizacji międzynarodowych, w tym przede wszystkim ugrupowań integracyjnych oraz bezpośrednich inwestycji zagranicznych, działań na rzecz liberalizacji polityki handlowej Światowej Organizacji Handlu, rosnącej roli regulacji prawnomiędzynarodowych. Występuje coraz więcej przepływów materialnych i niematerialnych, oddziaływań, zależności, układów dominacji i podporządkowania w skali regionalnej i globalnej. Państwa upodobniają się do siebie i są coraz wrażliwsze na zewnętrzne oddziaływania. Granice państw coraz łatwiej przekroczyć i są one coraz mniej zauważalne. Następuje deterytorializacja produktów, zjawisk i procesów. Coraz więcej kategorii, zwłaszcza ekonomicznych, rozpatruje się w skali ponadpaństwowej - globalne marki, przedsiębiorstwa, kryzysy, światowy lub regionalny pieniądz, światowe bezrobocie, światowa gospodarka czy też bardziej umownie - global governance. Rośnie też liczba wyzwań i problemów globalnych, których nie można powstrzymać granicami państw i którym pojedyncze państwo nie jest w stanie sprostać.

Rosnącej dezagregacji i hybrydyzacji podlega władza państwowa, którą trudno odróżnić od władzy ponadpaństwowej. W zglobalizowanym świecie występuje coraz więcej niepaństwowych, niewybieralnych, ponadnarodowych ośrodków decyzyjnych i grup nacisku - korporacje ponadpaństwowe, tzw. fundusze spekulacyjne, globalne i regionalne organizacje międzynarodowe. Potrafią one podporządkować sobie państwo i wpływać na jego działania oraz kondycję gospodarczą. Na skutek 
oligarchizacji władzy zatarciu ulegają granice pomiędzy władzą polityczną i gospodarczą. Przeciętny obywatel nie jest w stanie jednoznacznie stwierdzić, czy określona decyzja państwowa, np. w zakresie polityki społecznej, jest samodzielną decyzją rządu, czy też wynika z zewnętrznych zobowiązań lub nacisków; czy np. rosnące bezrobocie wynika z nieudolnej polityki państwa czy też z pogorszenia międzynarodowej koniunktury.

Rozmywają się też granice pomiędzy partiami politycznymi. Partie polityczne i ich programy upodobniają się do siebie. Coraz więcej partii to partie kadrowe, odideologizowane, partie władzy, których jedynym celem jest zdobycie i utrzymanie władzy, gra polityczna, niszczenie rywali, własne korzyści materialne, wywiązanie się ze zobowiązań wobec mocodawców i sponsorów i spełnianie ich oczekiwań, działania PR-owe i dbałość o własny wizerunek, dostosowanie zachowań do wyników badań sondażowych. Rządzi się przez kreowanie opinii publicznej. Nawet partiom, które mają inną wizję sprawowania władzy, zostają narzucone reguły gry. Określenia: partia konserwatywna, liberalna, socjaldemokratyczna, straciły na znaczeniu. Zgodnie z zasadami marketingu politycznego programy polityczne partii, jeżeli w ogóle istnieją, lokują się pośrodku rozkładu poglądów głosujących, tak aby nie zamykać sobie drogi do żadnej grupy wyborców [Lipset, Rokkan 1967: 26]. A. Giddens, a także T. Blair, G. Schröder twierdzą, że pojęcie lewicy i prawicy niewiele dziś znaczy, a polityka powinna być przede wszystkim racjonalna, tzn. centrowa, neoliberalna. Przyszłość, zdaniem polityków, optymalnie kształtuje wolny rynek. Ideologie straciły na znaczeniu, a dawne partie prawicy i lewicy stały się centrolewicą i centroprawicą [Żakowski 2006]. Ważne są pragmatyzm i skuteczność, a nie ideowość. D. Bell ogłosił w związku z tym koniec epoki ideologii, zauważając, że partie orientują swoje działania na podstawie pragmatycznych strategii zwiększania poparcia i sukcesu wyborczego [Bell 2000]. Lewica porzuciła słabszą część społeczeństwa, a prawica przybiera często pozę partii wrażliwych społecznie. Według G. Agambena, partie eliminują politykę, aby sprawować rządy i sterować ludźmi. Coraz częściej w związku z tym współrządzą główne partie na scenie politycznej, dawniej pozostające do siebie w ostrej opozycji [Kontrola 2006].

Partie polityczne wymieniają się pomysłami, celami i sposobami rozwiązywania problemów. W 2007 r. w Holandii rządziła koalicja partii chadeckiej, socjaldemokratycznej i fundamentalistycznej partii chrześcijańskiej Christen Unie. W Szwecji konserwatywna Partia Umiarkowana, zgodnie z poglądami większości Szwedów, popierała państwo opiekuńcze, walczyła o prawa kobiet i określała siebie jako partię pracobiorców. Zdolnościami adaptacyjnymi wykazał się były konserwatywno-liberalny premier Danii - Andres Fogh, który w głoszonych hasłach próbował łączyć liberalizm gospodarczy i elastyczność rynku pracy z bezpieczeństwem rynku pracy. Brytyjski przywódca konserwatystów David Cameron też bronił państwa opiekunczego, opowiadał się za tolerancją obyczajową i dużo uwagi poświęcał ochronie środowiska. Dopasowywanie się do oczekiwań wyborców Peer Steinbrück - były niemiecki minister finansów, nazywa politycznym piractwem [Perger 2007]. Coraz 
trudniej odróżnić polityka, dziennikarza, eksperta od piarowca, lobbysty, przedstawiciela kapitału. Politycy coraz częściej pełnią rolę aktorów wynajętych do odegrania zadanej roli, a po wykonaniu swojej misji otrzymują odpowiednią nagrodę.

Wybory i całe życie polityczne stało się reżyserowanym widowiskiem, spektaklem [Jamieson 1992: 42]. Jak stwierdził S. Tchakhotine, francuski psycholog społeczny zajmujący się propagandą polityczną, dbałość o skuteczność machiny politycznej stała się procesem tak nienaturalnym, że w najlepszym razie przypomina już tylko czysty marketing wyborczy, a w najgorszym staje się wręcz „gwałceniem thumu”. Agencje PR i posłuszni im politycy mogą podsycać poczucie społecznej bezradności i instrumentalnie manipulować strachem (przed terrorystami, przeciwnikami politycznymi, którzy jakoby mają autorytarne, dyktatorskie lub zbyt liberalne poglądy), aby przeciągnąć wyborców na swoją stronę [Nie kocham, 2006]. Potrafią preparować ruchy poparcia lub obywatelski protest, oburzenie i mobilizować opinię publiczną w sytuacji, gdy wybory ma szanse wygrać albo wygrywa ktoś spoza establishmentu - inspirują protesty i demonstracje społeczne, uruchamiają kampanie medialne, znajdują ekspertów odpowiednio komentujących sytuację oraz preparują „fakty” i oceny, formułują fałszywe dylematy i tworzą sztuczną rzeczywistość. Wymyśla się sztuczne problemy, które zaczynają żyć własnym życiem, aby „przykryć” te prawdziwe. Opinii publicznej coraz trudniej jest odróżnić prawdziwe wydarzenia, opinie, instytucje od tych kreowanych dla potrzeb kampanii wyborczych oraz wzmocnienia władzy politycznej i gospodarczej. Polityka, dostosowując się do wyników badań sondażowych albo kreując te wyniki, staje się sprzedażą obietnic sprawiających ludziom przyjemność, a debata publiczna polega na manipulowaniu faktami i dyskredytowaniu przeciwników politycznych. Przeciwników politycznych i ich poglądy niszczy się przez ośmieszanie, szyderstwo, poniżanie, wykluczanie i dehumanizację. Na rynku marketingu politycznego dużym zainteresowaniem cieszą się agencje zajmujące się tzw. czarnym PR. Powszechnie obecnym zjawiskiem w życiu politycznym i społecznym jest tzw. hejt i fake news. W celu wywołania społecznej dezorientacji i odwrócenia uwagi często spotykaną postawą jest przypisywanie przeciwnikowi własnych przewinień. Sposobem na zaistnienie oraz skuteczne sterowanie ludźmi jest też gra na emocjach i tworzenie głębokich podziałów społecznych oraz polaryzacja poglądów. Obowiązuje zasada „tolerujemy tylko tych, którzy myślą tak samo jak my”. Miejsce dawnej cenzury zajęła tzw. poprawność polityczna, oskarżenia o mowę nienawiści i system grantów. Społeczeństwo traci orientację w kwestii słuszności poglądów, uczciwych intencji i tego, kto rzeczywiście podejmuje decyzje, a kto tylko je firmuje.

Ludzie żyją więc w świecie symulowanym, w którym są poddani swoistej inżynierii społecznej w celu ukształtowania w nich sztucznej, symulowanej świadomości. Słowa tracą swoje zasadnicze znaczenie, np. dziś nie wystarczy użyć słowa demokracja, dla charakterystyki ustroju politycznego w jakimś państwie niezbędne wydaje się dodanie przedrostka lub przymiotnika, np. rozwinięta, stabilna, fasadowa, pozorowana, liberalna, ułomna, pluralistyczna, parlamentarna, partycypacyjna, formalna, oligarchiczna, autorytarna, sondażowa demokracja, półdemokracja, 
pseudodemokracja. Zatarciu ulegają granice pomiędzy demokracją, plutokracją merytokracją, autokracją i rządami oligarchii. Zdaniem politologów reprezentujących elitystyczne stanowisko (np. V. Pareto, G. Mosca), demokracja rozumiana jako rządy ludu, większości jest niemądrym urojeniem, władza bowiem zawsze jest sprawowana w imieniu uprzywilejowanej mniejszości [Heywood 2013: 167].

Nawet wojny są inscenizowane przez fachowców od PR, którzy pracują we wszystkich miejscach na świecie, gdzie są obecne amerykańskie wojska. Z oficjalnych dokumentów Pentagonu wynika, że resort obrony USA w latach 2000-2004 zawarł 35 umów na kwotę co najmniej 50 mln USD tylko z jedną agencją Rendon Group (PR). W Panamie agencja ta przygotowywała inwazję amerykańską, w Afganistanie pomagała wyjaśniać światu sens i małą szkodliwość nalotów dywanowych, do Kuwejtu w 1991 r. przybyła jeszcze przed żołnierzami USA, aby m.in. rozdać amerykańskie i brytyjskie chorągiewki, którymi „,rozentuzjazmowani” Kuwejtczycy mogliby witać zachodnich wybawicieli, poprawiała wizerunek USA w świecie islamskim przez zamawianie przyjaznych artykułów i opinii eksperckich, organizowanie wędrownych wystaw, np. w Iraku na temat okrucieństw Hussajna [Klawitter 2006].

Rozmyciu ulega również granica i skrócony dystans pomiędzy stanem wojny i pokoju. Pojawiły się nowe pojęcia, takie jak: wojna hybrydowa, wojna informacyjna, atak propagandowy, cybernetyczny lub aksjologiczny, wojna w białych rękawiczkach, wojna dyplomatyczna, ekonomiczna, które opisują różne stany pośrednie pomiędzy tradycyjnie rozumianym pokojem i wojną. Stanowią one określenia zastępcze, które ułatwiają odwrócenie uwagi i ukrycie rzeczywistości.

\section{ZMIANA ZNACZENIA POJĘĆ}

Coraz trudniej odróżnić też prawdę od fałszu, kłamstwa. Mówimy w związku z tym eufemistycznie o półprawdach, niepełnej prawdzie, prawdzie subiektywnej i obiektywnej, mojej i twojej prawdzie, o mijaniu się z prawdą, a nawet prawdą może być całkowita nieprawda. Według Stownika Oxfordzkiego za słowo roku 2016 uznano post-truth (postprawdę), które można thumaczyć jako okoliczności/sytuację, w których fakty mają mniejsze znaczenie w porównaniu $\mathrm{z}$ odwoływaniem się do emocji i osobistych przekonań. Użycie tego określenia wzrosło w 2016 r. o 2000\% w porównaniu z rokiem wcześniejszym. Uznanie komunikatu za zawierający prawdziwe, słuszne stwierdzenia zależy często nie od jego treści, ale od tego, kto jest jego autorem. Określenie to stanowi zaprzeczenie pojęcia prawdy. Przeciwnika dyskredytuje się przez permanentne ośmieszanie, wpajanie nienawiści, odczłowieczanie. Nadawcy informacji bardziej niż o fakty dbają o widowisko, oddziaływanie emocjonalne, narzucenie własnego systemu wartości i odpowiedniej interpretacji oraz emocjonalne zaangażowanie odbiorców. Prawda lub zasady moralne ustępują często miejsca skuteczności i użyteczności, które stanowią moralne usprawiedliwienie postępowania. Powszechnie spotykaną praktykąjest naginanie, przemilczanie, jednostronna interpretacja faktów, jednostronny dobór argumentów. Ety- 
ka jest zastępowana przez estetykę, a argumenty przez zmanipulowane obrazki. Pojęcia prawdy, wolności, sprawiedliwości tracą bezwzględny charakter, a często nawet swoje znaczenie, niekiedy nawet zamieniają się w swoje przeciwieństwo. Przykładem tego procesu jest, wydawać by się mogło, nawet tak jednoznaczne określenie jak ,niemieckie obozy koncentracyjne”, w którym przymiotnik ,niemiecki” kolejno zastępowano przymiotnikami: „,hitlerowskie”, „nazistowskie”, „faszystowskie”, a ostatnio coraz częściej spotkać można w zagranicznych, a zwłaszcza niemieckich mediach określenie: ,polskie obozy koncentracyjne”. Tak więc ofiary i mordercy zamienili się miejscami. Przykładem odwrócenia znaczenia pojęć są określenia: pracodawca i pracobiorca. W przeszłości pracodawca, jak sama nazwa wskazuje, był pracownikiem, osobą, która dawała pracę i otrzymywała za to wynagrodzenie, pracobiorca z kolei zatrudniał pracownika, brał jego pracę, za którą płacił płacę. Zachodziła więc relacja wymienna. Współcześnie, być może ze względów wizerunkowych lub doktrynalnych, zamieniono znaczenie tych pojęć - pracodawcą stał się podmiot gospodarczy, który daje pracownikowi zarówno pracę, jak i pieniądze, pracownik natomiast jest tylko biorcą: pracy i pieniędzy za nią. Symbolem przedstawionego procesu odwracania znaczeń jest działalność fikcyjnego Ministerstwa Prawdy opisana przez G. Orwella w Roku 1984: „Ministerstwo to, wbrew swojej nazwie, zajmuje się propagandą i fałszowaniem rzeczywistości oraz manipulowaniem ludzką świadomością, a na ścianie jego budynku są wymalowane trzy hasła: Wojna to pokój; Wolność to niewola; Ignorancja to siła” [Orwell 2013].

Słowa tracą swoje znaczenie, ulegają dewaluacji. Młodym, wychowanym we współczesnych realiach ludziom trudno zrozumieć powiedzenie ,,pewne jak w banku”, czy też sens określeń: wymiar sprawiedliwości, służba zdrowia. Politycy mówią o uczciwości, trosce o społeczeństwo, wolności jednostki, upodmiotowieniu społeczeństwa, sprawiedliwości, choć są to pojęcia dość odległe od codziennych odczuć i doświadczeń społeczeństwa, uczeni badają np. innowacyjność gospodarki i etykę biznesu, zalety decentralizacji władzy, wolność słowa, pluralizm polityczny, równość obywateli wobec prawa, wolną konkurencję, demokrację, nie zważając na drastyczne rozbieżności pomiędzy teorią a praktyką; sądy deklarują, że zawsze konsekwentnie dążą do sprawiedliwego osądzenia i ukarania winnych; dziennikarze twierdzą, że patrzą władzy na ręce i zawsze ujawniają obiektywną prawdę; urzędnicy deklarują, że w przetargach niezmiennie wybierają najlepszą ofertę; banki udzielają kredytów najbardziej wiarygodnym kredytobiorcom; lekarze i firmy farmaceutyczne przysięgają, że zawsze najważniejszą dla nich wartością jest dobro pacjenta; firmy zaś opowiadają się za uczciwą, konkurencją i deklarują, że najważniejsza dla nich jest realizacja misji, a nie zysk. Deklaracje te i związana z nimi rzeczywistość przypomina reklamę piwa bezalkoholowego z charakterystycznym przymrużeniem oka. Odbywają się pozorowane badania naukowe, kontrole, udawane medialne debaty, konsultacje społeczne, realizacje programów wyborczych. Ludzi otacza coraz więcej surogatów, ersatzów, imitacji - „mężów stanu”, „,uczonych”, „profesjonalistów”, „mędrców”, „ludzi honoru”, „,autorytetów”. Swobodnie manipuluje się faktami, fakty się naciąga albo kreuje. Pewne problemy znikają z publicznej debaty, inne wykazują 
nadobecność. Do określonych wartości, poglądów, stanowisk przekonują opinię publiczną ludzie przedstawiani jako eksperci w jakiejś dziedzinie lub jako autorytety. Pozorna bezstronność i naukowość ekspertyzy przesłania jej fałszywe założenia i pomaga uprawomocnić podejmowanie kontrowersyjnych i niekorzystnych dla większości społeczeństwa decyzji. Z. Bauman stwierdził: „Kiedyś wiadomo było, że politycy kłamią, więc ludzie szukali prawdy u rozmaitych ekspertów, autorytetów, mędrców. Dziś eksperci, intelektualiści i mędrcy coraz częściej kłamią równie bezkarnie, lekko jak politycy. [...] Pewnie nie ma już tezy tak absurdalnej, żeby nie dało jej się podeprzeć wynikami badań naukowych przeprowadzonych w uznanych ośrodkach" [Żakowski 2004]. Ludzie są zbyt zajęci swoimi sprawami i brakuje im kompetencji, aby zauważyć manipulacje, jakim są poddawani.

Zatarciu ulegają granice pomiędzy legalnym i nielegalnym, dozwolonym i zakazanym, etycznym i nieetycznym. Mówi się np. o naciąganiu prawa, poruszaniu się na granicy prawa, o różnych interpretacjach przepisów. Ujawnione nielegalne działania nazywa się eufemistycznie niezręcznością, wpadką, nadużyciem, niegospodarnością, optymalizacją, nieporozumieniem, błędem. W celu wywołania całkowitej dezorientacji coraz częściej spotykanym sposobem obrony jest oskarżanie oskarżającego o popełnione przez siebie czyny. Elity polityczne, jak również społeczeństwo jest coraz bardziej pobłażliwe, a nawet często solidaryzuje się czy wręcz podziwia za skuteczność bohaterów afer [Palumbo 2008]. Ludzie stają się obojętni, „znieczuleni" wobec rosnącej liczby przestępstw, nadużyć, przekraczania kolejnych granic i tabu. Coraz łaskawsze dla nich wydają się też systemy prawne. I tak, we Włoszech w latach 1996-2006 liczba wyroków skazujących w sprawach o korupcję spadła z 1194 do 186, w sprawach o marnotrawstwo publicznych pieniędzy z 608 do 210, w sprawach o wymuszanie łapówek z 555 do 53. W 2006 r. karę odsiedziało zaledwie $2 \%$ skazanych dzięki licznym prawnym „furtkom”, a średnia kara pozbawienia wolności nie przekraczała 2 lat [Palumbo 2008]. Zmniejsza się znaczenie zeznań „na gorąco" uzyskanych w trakcie przesłuchań niepotwierdzonych podczas rozpraw, skróceniu ulegają okresy przedawnienia, znosi się sankcje za przestępstwa finansowe, wprowadza się praktykę pertraktacji dotyczących wymiaru kary. Złagodzeniu ulega kwalifikacja przestępstw. W styczniu 2017 r. rząd rumuński podjął decyzję o depenalizacji przestępstw korupcyjnych oszacowanych na mniej niż 200 tys. zł, drastycznie obniżył kary za korupcję dotyczącą większych kwot pieniędzy oraz ogłosił amnestię m.in. dla wielu skorumpowanych polityków. Wbrew oczekiwaniom władz posunięcia te spowodowały masowe protesty społeczne.

Coraz częściej ludzie odbierają taki obraz świata, jaki przekazuje telewizja, a nie taki, jaki jest naprawdę [Kapuściński 2004]. Jak oceniają naukowcy, już na początku XXI wieku przynajmniej $40 \%$ informacji $\mathrm{w}$ gazetach pochodziła $\mathrm{z}$ agencji public relations (PR). Według badacza mediów M. Hallera, w Niemczech w pierwszej dekadzie XXI w. na 30 tys. dziennikarzy politycznych i gospodarczych przypadało około 18 tys. ludzi zajmujących się PR. W USA ich liczba jest zdecydowanie wyższa [Scott 2006: 196]. 
Na portalach internetowych, w prasie i telewizji wiadomości prawdziwe mieszają się z tymi wykreowanymi przez agencje PR i plotkami, a informacje dotyczące realnego świata $\mathrm{z}$ doniesieniami na temat losów postaci serialowych. Wiadomościami dnia są informacje o skandalach obyczajowych i zachowaniach tzw. celebrytów albo „wydarzenia" wymyślone przez specjalistów od PR.

Zdezorientowanym ludziom trudno też oddzielić informacje od interpretacji, dezinformacji, propagandy, zabiegów marketingowych. Promowanymi wartościami są elastyczność, mobilność, zmienność. Pozory mądrości, wiedzy, kompetencji mogą być efektem manipulacji, pseudoeksperckości i powoływania się na badania naukowe albo opinię publiczną. Wiedza jest mylona z umiejętnościami, mądrość i kompetencje z medialnością, a idol, celebryta, opłacony lobbysta z autorytetem. Subiektywna opinia lobbysty może być uznana za obiektywny, uzasadniony naukowo pogląd.

\section{ZAKOŃCZENIE}

Przedstawione procesy są efektem zarówno obiektywnych procesów związanych z postępem naukowo-technicznym, globalizacją, ekonomizacją i komercjalizacją życia, jak i celowych, zamierzonych działań. Odkąd odkryto moc manipulacji słowem i obrazem, zaczęto doskonalić jej techniki. Manipulacja, kłamstwo stały się przedmiotem badań naukowych i edukacji. Następuje dewaluacja pojęć, pomieszanie, a nawet odwracanie znaczeń i kryteriów, banalizacja i bagatelizacja problemów.

Konsekwencją zachodzących procesów jest przesuwanie, unieważnianie granic, zanikanie sfery tabu i sacrum, zmiana znaczeń i kryteriów wartości, dezorientacja ludzi, powszechna akceptacja dla relatywizmu rozumianego jako obojętność, znieczulenie, przyzwolenie na więcej/na wszystko. Przyczynia się to do utraty własnych przekonań, osobowości i zredukowania jej do wiązki odgrywanych ról, wykształcenia postaw zewnętrzsterownych. Ludzie bez własnych poglądów, tożsamości, wartości są zdezintegrowani, zagubieni i łatwiej nimi rządzić i manipulować. Coraz trudniej odpowiedzieć na pytania o własną tożsamość, która jest coraz bardziej złożona, wielowymiarowa, zmienna. Zatarciu ulega najważniejsza granica - pomiędzy dobrem i złem. Rozmywanie granic ułatwia ich przekraczanie i akceptację dla działań bezprawnych, nagannych, szkodliwych.

Nasileniu ulega antagonizm pomiędzy zwolennikami i przeciwnikami zachodzących procesów. Z jednej strony niepokój i opór wielu środowisk społecznych, religijnych wywołują prezentowane procesy, ich zasięg, szybkość i konsekwencje. $\mathrm{Z}$ drugiej, sprzeciw prowokuje każde działanie, którego celem jest odwrócenie prezentowanego trendu. Każdego, kto odwołuje się do jednoznacznych, opartych na tradycyjnych wartościach pojęć dobra, prawdy wolności, sprawiedliwości, oskarża się o wywoływanie konfliktów, fundamentalizm, zacofanie, prymitywizm, nieprzystawanie do współczesności. Stosunek do analizowanych przemian stał się nową, główną linią podziałów społecznych. 


\section{BIBLIOGRAFIA}

Bauman, Z. 2006. Płynna nowoczesność, Wydawnictwo Literackie, Warszawa.

Bell, D. 2000. The End of Ideology. On the Exhaustion of Political Ideas in the Fifties, Harvard University Press, New York.

Fulbeck, K., Spickard, P., Lennon, S. 2006. Part Asian, 100\% Hapa, Chronicle Books, San Francisco.

Heywood, A. 2013. Politologia, B. Maliszewska (tłum.), Wydawnictwo Naukowe PWN, Warszawa.

Jamieson, K.H. 1992. Dirty Politics. Deception, Distraction and Democracy, Oxford University Press, Oxford.

Kapuściński, R. 2004. Autoportret reportera, Społeczny Instytut Wydawniczy Znak, Kraków.

Klawitter, N. 2006. Psy propagandy zawsze do ushug, „Forum”, nr 32/33.

Kontrola jak nigdy. Rozmowa z G. Agambenem, 2006, „Forum”, nr 13.

Lipset, M., Rokkan, S. 1967. Party Systems and Voter Alignments, Cross-National Perspective, Free Press, New York.

Nie kocham Kasandry. Rozmowa z B. Barberem, 2006, „Forum”, nr 43/44.

Orwell, G. 1988. Rok 1984, T. Mirkowicz (tłum.), Państwowy Instytut Wydawniczy, Warszawa.

Palumbo, P. 2008. Brudne ręce Włoch, „Wprost”, 10.02.

Perger, W.A. 2007. Piraci demokracji, „Die Zeit” 4.10, za: „Forum”, nr 42.

Polak, E. 2009. Globalizacja a zróżnicowanie społeczno-ekonomiczne, Wydawnictwo Difin, Warszawa.

Polak, E., Polak, W. 2013. Ekonomizacja nierynkowych dziedzin życia i jej konsekwencje, „Contemporary Economy", nr 4 (1), s. 11-20.

Polak, E. 2012. Niby-rzeczywistość $i$ warunki osiagnięcia w niej sukcesu, „Transformacje. Pismo Interdyscyplinarne", nr 1-4 (72-75), s. 182-202.

Scott, J. 2006. Władza, S. Królak (tłum.), Wydawnictwo Sic!, Warszawa.

Sztumski, W. 2015. Granica między sacrum a profanum, http://www.sprawynauki.edu.pl/index.php?option=com_content\&view=article\&id=2341:granica-midzy-sacrum-a-profanum\&catid=288\&Itemid=30 (dostęp: 1.03.2017).

Żakowski, J. 2014. Wielkie kłamstwa. Rozmowa z Z. Baumanem, „Niezbędnik Inteligenta” (dodatek do „Polityki”), 21.12.

Żakowski, J. 2006. Pochwała namiętnej różnicy. Rozmowa z Ch. Mouffe, „Niezbędnik Inteligenta” (dodatek do „Polityki”), 18.06.

\section{BLURRING BORDERS AND CHANGING MEANINGS AS ONE OF THE TENDENCIES OF CONTEMPORARY CIVILIZATIONAL CHANGES}

Abstract: The present work is devoted to the analysis of the directions of contemporary cultural changes, their nature, causes, consequences and conflicts arising on the background of the processes. The structure of work includes an introduction, six chapters, and a summary.

To resolve the problem of the research, the following methods has been applied: analysis of the literature and press reports, and direct and indirect observation. The survey of literature on the subject allowed the juxtaposition of the author's own thoughts and observations with previous research findings. The method consisting in the synthesis of scattered information and observation was applied.

Keywords: blurring borders, changing meanings, cultural changes 


\section{BIOGRAM}

Ewa Polak, prof. dr hab., zatrudniona na Wydziale Ekonomicznym Uniwersytetu Gdańskiego. Zajmuje się polityką gospodarczą i społeczną oraz przemianami cywilizacji współczesnej z uwzględnieniem globalizacji i integracji. Jest autorką i współautorką książek: Przemiany cywilizacji wspótczesnej w sferze kultury materialnej (Gdańsk 1996) i Przemiany cywilizacji wspótczesnej w sferze kultury duchowej (wraz z J. Leską-Ślęzak, Gdańsk 1999), Dezintegracja i integracja jako wspótzależne procesy współczesnych przemian cywilizacyjnych (Gdańsk 2001), a także autorką około 60 artykułów naukowych. Kontakt e-mail: polakewa@wp.pl. 